\title{
Detection of Mycoplasma gallisepticum Infection in Turkey and Chicken Farms of Tamilnadu, India
}

\author{
M. Prabhu ${ }^{1,2 *}$, S. Malmarugan ${ }^{1}$, N. Sweetline Anne ${ }^{1}$, S. Parthiban ${ }^{1}$, \\ G. Balakrishnan ${ }^{1}$ and J. Johnson Rajeswar ${ }^{1}$
}

${ }^{1}$ Department of Veterinary Microbiology, Veterinary College and Research Institute, Tamilnadu Veterinary and Animal Sciences University, Tirunelveli, Tamilnadu, India

${ }^{2}$ Department of Veterinary Microbiology, Veterinary College and Research Institute, Namakkal, Tamilnadu, India

*Corresponding author

\section{A B S T R A C T}

\section{Keywords}

Chicken, Turkey, Mycoplasma gallisepticum, Infectious sinusitis, Isolation, PPLO agar, PCR

\section{Article Info}

Accepted: 20 December 2020 Available Online: 10 January 2021
Mycoplasma gallisepticum (MG) is the most pathogenic avian mycoplasmas and is worldwide in distribution. It is economically significant pathogen causing Chronic Respiratory Disease in chicken and Infectious sinusitis in Turkeys. The current investigation deals with detection of MG infection in chicken and turkeys from the poultry flocks of Tirunelveli and Kanyakumari districts of Tamilnadu, India. Affected turkeys showed congestion of conjunctival mucous membrane, mild respiratory rales, nasal discharge, dullness and unilateral and/or bilateral swelling of infraorbital sinuses. Here we report $14.13 \%$ and $10.97 \%$ of morbidity and mortality, respectively among affected turkey. A total of 34 poultry samples including 11 samples from turkey collected during the period from March 2017 to February 2019 have been screened. The etiological agent was confirmed based on isolation, genus specific and species specific PCRs. The samples were cultured in PPLO agar and incubated at $37^{\circ} \mathrm{C}$ under $5 \% \quad \mathrm{CO}_{2}$ to reveal fried egg appearance under microscope. Further, the samples were subjected to genus specific PCR followed by MG species specific PCR which yielded specific amplicons of $715 \mathrm{bp}$ and $185 \mathrm{bp}$, respectively in positive cases. The report supports the use of molecular PCR without the need for laborious culture identification for direct screening of field samples.

\section{Introduction}

Avian mycoplasmas are smallest, cell wall less, self-replicating bacteria that are described to cause infections of poultry since 1900s. Mycoplasmal infection was described for the first time as a respiratory disease in turkeys in 1926 and later in chickens in the year 1936 (Charlton et al., 1996). Of four pathogenic avian mycoplasma species, Mycoplasma gallisepticum (MG) has been described as highly infectious respiratory pathogen of poultry causing chronic respiratory disease (CRD) in chicken and infectious sinusitis in turkeys. Other species include $M$. synoviae of chicken and turkey; $M$. 
meleagridis and $M$. iowae, the less significant species of only turkeys (Prajapati et al., 2018).

MG is one of the most significant poultry pathogen affecting a wide range of birds including many wild birds (Dhondt et al., 2005). The systematic review and metaanalysis revealed the presence of MG in 56 species of birds belonging to 11 different orders (Sawicka et al., 2020). Hence, many wild bird species could be considered as possible reservoirs or carriers of MG. It is transmitted either vertically through eggs or horizontally by infectious aerosol and contaminated environment. $\mathrm{MG}$ infection is mainly characterized by sneezing, respiratory rales, coughing, nasal and ocular discharges in chicken (Gondal et al., 2015). In turkeys, the infection is characterized by sinusitis (swelling of the infra orbital sinus), conjunctivitis and frothy exudates (Peebles and Branton, 2012). Though MG can affect all age groups of chicken and turkey, young birds are more susceptible (Nunoya et al., 1995) and is particularly more common among commercial layer chicken of upto 32 weeks old (Udhayavel et al., 2016). In pheasants, partridges, quail, ducks, geese and other avian species, it causes sinusitis and conjunctivitis (Saif and Jarosz 1978; Ley 2008). In the recent past, the MG outbreaks have caused considerable economic losses to the poultry industry by reduced weight gain, decreased feed conversion ratio, increased condemnation during slaughter and increased mortality in broilers; it causes significant reduction in egg production among layers; and results in increased embryonic mortality, reduced hatchability and quality of day-old chicks in breeder flocks (Ley, 2008; Bharathi et al., 2018). In layers, the production losses between 10-20\% have been reported (Bradbury, 2001). The additional cost on vaccination, medication and disinfection procedures also makes this disease one of the expensive health problems among the poultry farmers. It creates trouble in terms of food safety, antibacterial drug resistance and drug residual issues (Saif and Jarosz 1978).

The diagnoses of avian mycoplasmosis mainly rely on serological, cultural and molecular tests. Serological tests such as serum plate agglutination (SPA) test, hemagglutination inhibition (HI) test and enzyme-linked immunosorbent assays (ELISA) are the most widely used tests for the diagnosis and sero-surveillance (OIE, 2008). However, this sero-diagnosis at times is hampered by interspecies cross-reactions and nonspecific reactions (Hagan et al., 2004). Hence, this screening has to be further confirmed by cultural identification and PCR detection (Ramadass et al., 2006). Though MG was successfully cultured since 1960 by Edward and Kanarek (1960), the isolation is always a very difficult and cumbersome process to perform. Therefore, molecular PCR methods that are more specific, sensitive and effective could be more useful in diagnosis of MG infections.

Infections caused by MG have been familiar in India for many years. However, the reports mainly are based on serological studies with few literatures on bacteriological and molecular diagnosis. The current study deals with the occurrence, diagnosis and management of CRD and infectious sinusitis in chicken and turkeys, respectively from the poultry flocks of Tirunelveli and Kanyakumari districts of Tamilnadu, a Southern state of India.

\section{Materials and Methods}

\section{Clinical appraisal and sample collection}

Two turkey farms each one from Tirunelveli and Kanyakumari districts, were reported with respiratory signs, nasal discharge and 
swelling around the eyes of turkey. A total of 580 turkey birds of age group from 60 days to 1 year were housed as flocks in deep litter system. During investigation, 82 sick turkey birds were kept isolated and were showing clinical signs such as congestion of conjunctival mucous membrane, mild respiratory rales, nasal discharge, dullness and unilateral and/or bilateral swelling of infraorbital sinuses. It was also reported that, 9 turkeys died during the past one week, but no bird has been retained for necropsy. Hence, clinical specimen like edematous / cheesy exudate from infra orbital swelling and nasal, tracheal, choanal cleft swabs $(n=11)$ were collected from live sick birds.

In addition, samples received from other poultry species such as chicken (both desi chicken and commercial broiler/layer birds) and quail suspected for $\mathrm{MG}$ were also included in the study during the period from March 2017 to February 2019. A total of 23 samples including swabs from choanal cleft, trachea and lung tissue samples collected during the necropsy at Veterinary College and Research Institute, Tirunelveli were also subjected to screening and molecular detection.

\section{Bacterial isolation}

Swabs were cultured as previously recommended by Bradbury (1998). Swabs collected from the infraorbital sinus, trachea and nasal/ocular discharges and cheesy material from infraorbital sinuses were inoculated into the PPLO (pleuropneumonialike organism) broth and incubated for 2-3 days at $37{ }^{\circ} \mathrm{C}$ under $5 \% \mathrm{CO}_{2}$ tension. Further, they were subcultured on PPLO agar (HiMedia, India) plates on color change in broth culture and incubated for 5-7 days at 37 ${ }^{\circ} \mathrm{C}$ under $5 \% \quad \mathrm{CO}_{2}$ tension. The isolated bacteria were identified as MG using both genus-specific and species-specific polymerase chain reaction (PCR). In addition to mycoplasma isolation, the samples were also subjected to routine bacteriological examination. Samples collected from the infraorbital sinuses, swabs and tissues were processed on nutrient agar, blood agar, MacConkey agar and Eosin-Methylene Blue (EMB) agar and incubated at $37{ }^{\circ} \mathrm{C}$ for $24-48$ h. The culture positive samples were subjected to Antibiotic Susceptibility Testing (ABST) by using the Kirby-Bauer agar disk diffusion method (Bauer et al., 1966) with commercially available antibiotic disks (Himedia, India).

\section{DNA extraction and molecular detection}

Suspected samples were processed for DNA extraction as described earlier with minor modifications (Rasoulinezhad et al., 2017; Bharathi et al., 2018). Broth culture $(500 \mu \mathrm{L})$ suspected for Mycoplasma sp. or swabs suspended in PBS were centrifuged at 12,000 rpm for $10 \mathrm{~min}$. The supernatant was removed and the pellet was washed twice with PBS. Then the pellet was dissolved in $30 \mu \mathrm{l}$ molecular grade water. The contents in the micro centrifuge tubes were boiled at $95^{\circ} \mathrm{C}$ for $10 \mathrm{~min}$ followed by immediate cooling at $20^{\circ} \mathrm{C}$ for $5 \mathrm{~min}$ before centrifugation at $10,000 \mathrm{rpm}$ for $5 \mathrm{~min}$ and the supernatant was used as the template DNA for the PCR. However, tissue samples were triturated directly in pestle and mortar and the genomic DNA was extracted using DNeasy Blood \& Tissue Kit® (Qiagen, Germany) following manufacturer's instructions and the extracted DNA was kept at $-20^{\circ} \mathrm{C}$ till use.

Molecular detection was carried out by employing the primers particular for genusspecific and species-specific PCRs as descried before by Kuppeveld et al., (1992) and Lauerman (1998), respectively (Table 1). Each PCR reaction mixture contained 12.5 $\mu$ l of 2X Taq DNA Polymerase Master Mix 
RED (Ampliqon, Denmark), $1 \mu \mathrm{l}(10 \mathrm{pM})$ of each forward and reverse primers, 2-3 $\mu$ l of extracted DNA as template and adjusted to the final volume of $25 \mu \mathrm{l}$ by adding nucleasefree water and then subjected to amplification in thermocycler (Eppendorf Mastercycler ${ }^{\circledR}$ nexus X2, Germany). Finally, agarose gel electrophoresis (1.5\% agar) was carried out to visualize the PCR products and the images were captured by gel documentation system.

\section{Results and Discussion}

Mycoplasma gallisepticum is one of the highly important infectious diseases that influence commercial poultry production worldwide (Swayne et al., 2013). The clinically affected chicken and turkey show the clinical signs such as congestion of conjunctival mucous membrane, dullness, ruffled feathers, nasal discharge, coughing, sneezing, respiratory rales and unilateral and/or bilateral swelling of the head particularly in the periorbital region. Our investigation also supports such findings with severe swelling of infraorbital sinuses (Fig.1). The main clinical observations are respiratory signs and poor bodily conditions which are similar to earlier reports (Saif et al., 2003; Bharathi et al., 2018).

Though reported commonly from poultry farms, the literature from turkey flock is scanty. Rasoulinezhad et al., (2017) reported the per cent positivity of $16.66 \%$ and $48.38 \%$, among commercial and backyard turkey farms, respectively in Iran. In India, Rajkumar et al., (2018) reported $11.65 \%$ prevalence of MG in seven states of India including Tamilnadu. Bharathi et al., (2018), revealed the morbidity of 3.67 and $6.75 \%$ and mortality of 0.91 and $0.67 \%$ in chickens and turkeys respectively. Our findings demonstrated that the prevalence of MG was higher in turkeys with $14.13 \%$ and $10.97 \%$ of morbidity and mortality, respectively in southern districts of Tamilnadu. However, we could not calculate the prevalence in chicken as we processed only samples spared others.

Table.1 Details of the Primers used in the study

\begin{tabular}{|c|l|l|c|}
\hline $\begin{array}{c}\text { S. } \\
\text { No }\end{array}$ & $\begin{array}{c}\text { Name of the } \\
\text { Primer }\end{array}$ & \multicolumn{1}{|c|}{ Primer sequence (5'-3') } & $\begin{array}{c}\text { Amplicon } \\
\text { size }\end{array}$ \\
\hline \multirow{2}{*}{ 1. } & GPO-1 & ACTCCTACGGGAGG CAGCAGTA & $715 \mathrm{bp}$ \\
\cline { 2 - 4 } & MGSO & TGCACCATCTGTCACTCTGTTAACCTC & \\
\hline \multirow{2}{*}{ 2. } & MG-14F & GAGCTAATCTGTAAAGTTGGTC & \multirow{2}{*}{$185 \mathrm{bp}$} \\
\cline { 2 - 3 } & MG-13R & GCTTCCTTGCGGTT AGCAAC & \\
\hline
\end{tabular}

Fig.1 Infectious sinusitis of turkey showing characteristic swelling of infra-orbital sinuses

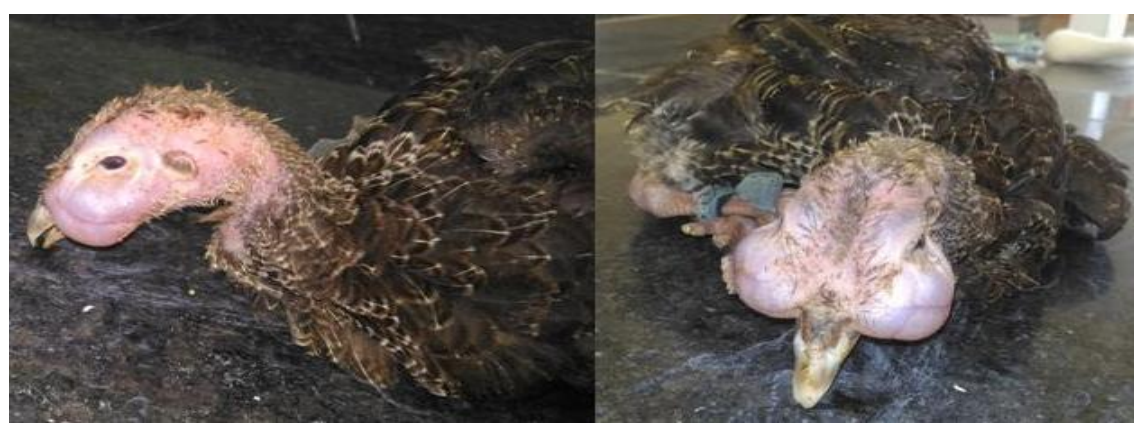


Fig.2 Fried egg appearance of Mycoplasma gallisepticum colonies in PPLO agar observed under stereo microscope (40x)

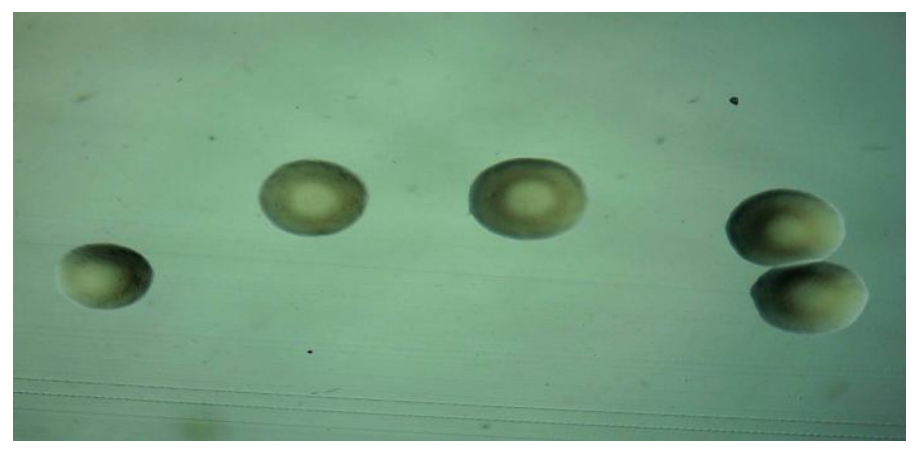

Fig.3 Mycoplasma genus specific PCR

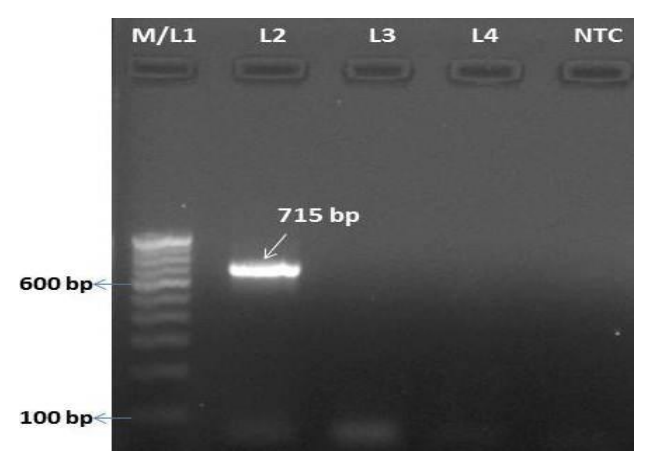

Lane M/L1: 100 bp DNA ladder; L2: Positive sample L3-4: Negative samples; NTC: Non-template control

Fig.4 Mycoplasma gallisepticum species specific PCR

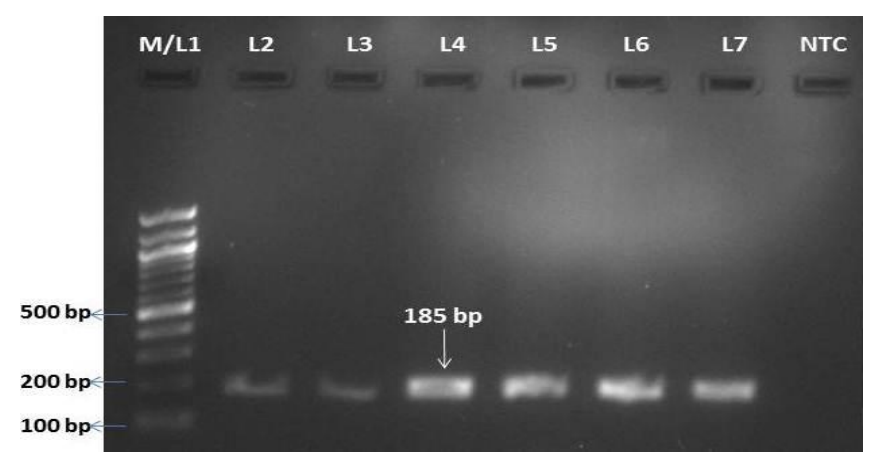

\section{Bacterial isolation}

On isolation in PPLO broth, there was visible colour change in 2 days after incubation. Further, on PPLO agar, colonies appeared after 3-4 days of incubation and resembled the appearance of fried egg under stereo microscope (Fig.2) as reported previously (Khalifa et al., 2013). Here, we could observe such morphology only in three isolates, each one from of infraorbital sinus of turkey and tissue samples and cheesy exudate from infraorbital sinuses of chicken. 
Further, the infections caused by MG at times stay without obvious clinical signs, but may make the birds susceptible to secondary infections with bacteria such as Escherichia coli and respiratory viruses in turkeys (Gross, 1990; Kleven, 1998). It was also reported that the presence of concurrent infections by ranikhet disease virus, infectious bronchitis virus, colibacillosis or other pathogens usually aggravate the severity of the infection (Prajapati et al., 2018; Nneoma Okwara, 2016). In the present study, on routine bacteriological examination, E. coli $(\mathrm{n}=6)$ and Staphylococcus aureus $(\mathrm{n}=1)$ could be also be isolated from chicken that must have accounted for mortality. ABST revealed the sensitivity of such bacteria to antibiotics such as Amikacin, Gentamicin, Enrofloxacin to control these concurrent infections.

\section{Molecular detection}

The Mycoplasma genus specific PCR yielded the amplicon size of $715 \mathrm{bp}$ from infraorbital sinuses, cheesy exudates and lung tissue samples (Fig.3). But, MG species specific PCR showed the positive product size of 185 bp (Fig 4). These fastidious Mycoplasma are very hard to culture, requires long incubation, involves microscopic examination to witness colonies and initial cultures in addition may contain other contaminants (Kleven, 2008, Bagheri et al., 2011). Hence the species specific PCR can be employed for rapid screening of field samples before the culture results are obtained. Out of 34 samples tested, 7 turkey samples $(63.63 \%)$ and 9 chicken samples $(39.13 \%)$ were found positive for the MG by PCRs. The current study also supports the direct use of PCR without the need for culturing (McAuliffe et al., 2005; Singh et al., 2013).

The turkey flock owners were advised to isolate the sick birds and to treat with $1 \%$ Tylosin for 3-5 days (Kalu et al., 2015). Other susceptible birds in the flock also were advised to be treated prophylactically with $0.5 \%$ Tylosin in drinking water for 3 days to avoid the spread of infection.

In conclusion, the present study confirms the presence of $\mathrm{MG}$ infection in turkey and chicken flocks of Southern districts of Tamilnadu based on bacteriological and molecular detection methods. Hence, the regular surveillance and routine vaccination are to be done to curtail the spread of infection. The PCR methods could be employed for early diagnosis, so that the biosecurity and control measures could be adopted well in advance to prevent the economic loss.

\section{Acknowledgements}

The authors are thankful to the staff and technician of Departments of Veterinary Microbiology and Veterinary Pathology, Veterinary College and Research Institute, TANUVAS, Tirunelveli - 627 358, for providing necessary support to carry out the study.

\section{References}

Bagheri, H., Doosti, A. and Arshi, A. 2011. Detection of Mycoplasma gallisepticum in Chaharmahal Va Bakhtiari Province Poultry Using PCR. Glob. Vet. 7 (1): 5459.

Bauer, A.W., Kirby, W.M., Sherris, J.C. and Turck, M. 1966. Antibiotic susceptibility testing by a standardized single disk method. Am. J. Clin. Pathol. 45:493-496.

Bharathi, R., Karthik, K., Mahaprabhu, R., Manimaran, K., Geetha, T., Tensingh Gnanaraj, P. and Roy. P.R. 2018. Outbreak and management of Mycoplasma gallisepticum infection in desi chicken and turkey flocks in an organized mixed farm. Comp. Clin. Pathol. 27: 621-625. https://doi.org/10.1007/s00580-018-2637-1

Bradbury, J.B. 1998. Recovery of mycoplasmas 
from birds. In: Miles RJ, Nicholas RAJ (eds) Methods in Molecular Biology. Vol. 104, Humana Press Inc, New Jersey, pp 4551

Bradbury, J.M. 2001. Avian mycoplasmosis. In: Jordan F, Pattison M, Alexander D, Fragher T (eds) Poultry diseases, 5th edn. W.B. Saunders Company, Iowa, pp 178-193

Charlton, B.R., Bermudez, A.J., Boulianne, M., Eckroade, R.J., Jeffrey, J.S., Newman, L.J., et al., 1996. Avian mycoplasmosis. In: Charlton BR, editor. Avian Disease Manual. Pennsylvania: American Association of Avian Pathologists; pp. 115125

Dhondt, A.A., Altizer, S., Cooch, E.G., Davis, A.K., Dobson, A., Driscoll, M.J.L., et al., 2005. Dynamics of a novel pathogen in an avian host: Mycoplasmal conjunctivitis in house finches. Acta Trop. 94: 77-93. https://

doi.org/10.1016/j.actatropica.2005.01.009

Edward, D.G.F. and Kanarek, A.D. 1960. Organisms of the pleuropneumonia group of avian origin: their classification into species. Ann. N.Y. Acad. Sci. 79: 696-702. https://doi.org/10.1111/j.1749-6632.1960. tb42744.x

Gondal, M.A., Rabbani, M., Muhammad, K., Yaqub, T., Babar, M.E., Sheikh, A.A., Ahmad, A., Shabbir, M.Z. and Khan, M.I. 2015. Characterization of Mycoplasma gallisepticum isolated from commercial poultry flocks. J. Anim. Plant. Sci. 25(1):108-113

Gross, W.B. 1990. Factors affecting the development of respiratory disease complex in chickens. Avian Dis. 1:607-610.

Hagan, J.C., Ashton, N.J., Bradbury, J.M. and Morgan, K.L. 2004. Evaluation of an egg yolk enzyme-linked immunosorbent assay antibody test and its use to assess the prevalence of Mycoplasma synoviae in UK laying hens. Av. Path. 33: 1335-38

Kalu, N., Chah, K.F., Anene, B.M. and Ezema, W. 2015. Respiratory mycoplasma infection in chickens in Nsukka AgroEcological Zone, Enugu State, Nigeria. $J$. Vet. Adv. 5(7):1036-1045

Khalifa, K.A., Abdelrahim, E.S., Badwi, M. and Mohamed, A.M. 2013. Isolation and molecular characterization of Mycoplasma gallisepticum and Mycoplasma synoviae in chickens in Sudan. J. Vet. Med. Volume 2013, Article ID 208026, 4 pages. https://doi.org/10.1155/2013/208026

Kleven, S.H. 1998. Mycoplasmas in the etiology of multifactorial respiratory disease. Poult. Sci. 77(8): 1146-1149.

Kleven, S.H. 2008. Mycoplasmosis. In: A Laboratory Manual for the Isolation, Identification, and Characterization of Avian Pathogens. L. Dufour-Zavala, D. E. Swayne, J. R. Glisson, J. E. Pearson, W. M. Reed, M. W. Jackwood and P. R. Woolcock, eds. American Association of Avian Pathologists, Athens, GA. pp 59-64.

Kuppeveld, F.J.M., Logt, J.T.M.V,, Angulo, A.F,, Zoest, M.O.V,, Quint, W.G.V,, Neisters, H.G.M,, Galama J.M.D. and Melchers, W.J.G. 1992. Genus and species specific identification of mycoplasmas by $16 \mathrm{~s}$ rRNA amplification. Appl. Environ. Microbiol. 58(8):2606-2615

Lauerman, L.H. 1998. Mycoplasma PCR assays. In: Lauerman LH (ed) Nucleic amplification assays for diagnosis of animal diseases, American Association of Veterinary Laboratory Diagnosticians, Auburn, AL, USA, pp 41-52

Ley, D.H. 2008. Mycoplasma gallisepticum infection. In: Diseases of poultry, Ames, Iowa State University Press. USA, pp. 805833

McAuliffe, L., Ellis, R.J., Lawes, J.R., Ayling, R.D. and Nicholas, R.A.J. 2005. 16S rDNA PCR and denaturing gradient gel electrophoresis; a single generic test for detecting and differentiating Mycoplasma species. J.Med Microbiol. 54: 731-739.

NneomaOkwara. 2016. Avian Mycoplasmosis: A Review. J. Agricult. Vet. Sci. 9: 6-10.

Nunoya, T., Yagihashi, T., Tajima, M. and Nagasawa, Y. 1995. Occurrence of keratoconjunctivitis apparently caused by Mycoplasma gallisepticum in layer chickens. Vet. Pathol. 32(1):11-18. https:// doi.org/10.1177/030098589503200102

OIE. 2008. Manual of Diagnostic tests and Vaccines for Terrestrial Animals. Chapter 2.3.5: Avian mycoplasmosis (Mycoplasma gallisepticum, M. synoviae), pp. 482-496. 
Peebles, E.D. and Branton, S.L. 2012. Mycoplasma gallisepticum in the commercial egg-laying hen: A historical perspective considering the effects of pathogen strain, age of the bird at inoculation, and diet on performance and physiology. J. App. Poult. Res. 21: 897914.

Prajapati, A.. Subhashree, N., Siju Susan. J., Manjunath G.B. Reddy., Yogisharadhya, R. and Patil. S.S. 2018. Prevalence of Mycoplasma gallisepticum and Mycoplasma synovae in Poultry- India Perspective A. Int. J. Curr. Microbiol. App. Sci. 7(5): 2213-2220. https://doi.org/10.20546/ijcmas.2018.705.2 58.

Rajkumar, S., Reddy, M.R. and Somvanshi, R. 2018. Molecular prevalence and seroprevalence of Mycoplasma gallisepticum and $M$. synoviae in Indian Poultry Flocks. J. Anim. Res. 8: 15-19

Ramadass, P., Ananthi, R., Senthilkumar, T.M.A., Venkatesh, G. and Ramaswamy, V. 2006. Isolation and characterization of Mycoplasma gallisepticum and Mycoplasma synoviae from poultry. Ind. J. Ani. Sci. 76 (10): 796-798

Rasoulinezhad, S., Bozorgmehrifard, M.H., Hosseini, H., Sheikhi, N. and Charkhkar, S. 2017. Molecular detection and phylogenetic analysis of Mycoplasma gallisepticum from backyard and commercial turkey flocks in Iran. Veterinary Research Forum, 8 (4):
$293-298$

Saif, Y.M. and Jarosz, F. 1978. Neotetrazolium staining of three avian Mycoplasma serotypes for microagglutination test. Avian Dis. 22(2):358-361. https://doi.org/10.2307/1589551

Saif, Y.M.H,, Barnes, J., Glisson, J.R., Fadly, A.M., McDougald, L.R. and Swayne, D.E. 2003. Diseases of poultry, $11^{\text {th }}$ edn. Iowa State University Press, Ames, pp 719-745

Sawicka, A., Durkalec, M., Tomczyk, G. and Kursa, O. 2020. Occurrence of Mycoplasma gallisepticum in wild birds: A systematic review and meta-analysis. PLoS ONE.15(4): e0231545. https:// doi.org/10.1371/journal.pone.0231545

Singh, D., Mahajan, N.K., Kumar, A., Maan, S. and Kumar, P. 2013. Detection of Mycoplasma gallisepticum from field samples of poultry using conventional PCR. Adv. Anim. Vet. Sci. 1 (1S): 11-13

Swayne, D.E., Glisson, R.J, McDougald, L.R., et al., 2013. Mycoplasma gallisepticum infection. In: Swayne DE (Ed). Diseases of poultry. $13^{\text {th }}$ ed. Ames, USA: Blackwell Publishing Professional; 877-893.

Udhayavel, S., Murthy, T.R.G.K., Gowthaman, V., Senthilvel, K. and Sureshkumar, G. 2016. Detection of sub clinical infection of Mycoplasma gallisepticum in commercial chicken by indirect ELISA. Adv. Anim. Vet. Sci. 4(8): 438-440

\section{How to cite this article:}

Prabhu, M., S. Malmarugan, N. Sweetline Anne, S. Parthiban, G. Balakrishnan and Johnson Rajeswar, J. 2021. Detection of Mycoplasma gallisepticum Infection in Turkey and Chicken Farms of Tamilnadu, India. Int.J.Curr.Microbiol.App.Sci. 10(01): 3151-3158. doi: https://doi.org/10.20546/ijcmas.2021.1001.367 